\title{
S100A9 wt Allele
}

National Cancer Institute

\section{Source}

National Cancer Institute. S100A9 wt Allele. NCI Thesaurus. Code C52264.

Human S100A9 wild-type allele is located within $1 \mathrm{q} 21$ and is approximately $3 \mathrm{~kb}$ in length.

This allele, which encodes S100-A9 protein, plays a role in several cellular processes such as cell cycle progression and differentiation and may play a role in protein kinase inhibition. 